\title{
The Biochemical investigation and analysis to determine a potent biomarker for HCC and HCV infections
}

\author{
Vijay Kumar ${ }^{1} \cdot$ Priya Thapliyal $^{2} \cdot$ Rajesh $_{\text {Rayal }}{ }^{3} \cdot$ Baljeet Singh Saharan $^{4} \bullet$ Arun Kumar $^{5} \cdot$ Shweta \\ Sahni $^{{ }^{*}}$ \\ ${ }^{I}$ Department of Microbiology, School of Basic and Applied Sciences, Shri Guru Ram Rai University, Patel \\ Nagar, Dehradun, Uttarakhand, India. \\ ${ }^{2}$ Department of Biochemistry, H.N.B. Garhwal, University, Srinagar, Uttarakhand, India. \\ ${ }^{3}$ Department of Zoology, School of Basic and Applied Sciences, Shri Guru Ram Rai University, Patel Nagar, \\ Dehradun, Uttarakhand, India. \\ ${ }^{4}$ Department of Microbiology CCS University, Hisar, Haryana, India. \\ ${ }^{5}$ Department of Biotechnology, School of Basic and Applied Sciences, Shri Guru Ram Rai University, Patel \\ Nagar, Dehradun, Uttarakhand, India.
}

*Corresponding Author Email Id: drshwetasahni@gmail.com

Received: 20.10.2021; Revised: 7.11.2021; Accepted: 24.11.2021

OSociety for Himalayan Action Research and Development

\begin{abstract}
The communicable Hepatitis C Virus (HCV) infection causes global health problems and deaths due to transmission by blood and body fluids and general symptoms include loss of appetite, fatigue, fever, abdominal pain, swelling, jaundice, and dark urine.This study contains a detailed study about the potent biochemical biomarkers for the diagnosis and detection of $\mathrm{HCV}$ infection. It includes the biochemical profiling relating to the $\mathrm{HCV}$ infection among both the genders of the human population is included in this paper.96 (5ml) EDTA blood samples of suspected HCV infected patients were collected from the different hospitals in Dehradun, Uttarakhand, India. The RNA extraction was performedwith the help of QIAamp Viral RNA mini kit (Cat. no. 52904). The HCV RNA quantification was achieved using the machine named Rotor Gene Q5 Plex Real-Time PCR and master mix was prepared by the Artus Amplification Kit from Qiagen.Out of 96 samples collected for HCV RNA biochemical profiling, 58 cases i.e., were found with the heavy load of virus and the study had 38 cases in which target virus was not detected. The biochemical investigation was performed on 96 cases with a high viral load of more than $34 \mathrm{IU} / \mathrm{ml}$ ( $\geq 34 \mathrm{IU} / \mathrm{ml})$. The cases belonging to age 21-40 and 41-60 years were found to be most prominent among 35 and 37 cases respectively due to the repeated exposure to infected blood and the age group of 0-20 years was found to be least susceptible due to the protective antibody titer against $\mathrm{HCV}$ due to the vaccination in early age.
\end{abstract}

Keywords: Hepatitis C Virus (HCV); Real-Time Polymerase Chain Reaction (RT-PCR); Biochemical profiling; SGOT; SGPT; Alkaline phosphatase; Bilirubin; Globulin

\section{Introduction}

The contagious liver disease is caused by an endogenous, infectious viral agent called the Hepatitis C virus (HCV)(Nelsonet al., 2011). Hepatitis C Virus (HCV) is related to the global health problem due to the symptoms like chronic liver diseases, progression to cirrhosis and hepatocellular cancer (Kuriyal et al. 2019). It acts as an etiological viral agent that is transmitted by blood and blood transfusion. Such blood transfusion can occur by contact with the infected body fluids, sharing needles and other items which came in contact with the infected individuals. The common symptom includes loss of appetite, fatigue, fever, abdominal pain, swelling, jaundice, and dark urine (Mahmood et al., 2013). It belongs to the Hepacivirus genus 
within the Flaviviridae family. Its viral structure is enveloped with a single RNA positive strand of $50 \mathrm{~nm}$ diameter and $9.5 \mathrm{~kb}$ genome (Fujimoto el al. 2012). The internal ribosome translates the polyprotein encoded by the genomic RNA which is later on followed by cleaving itself with the help of viral proteases into the ten mature viral proteins(Moriishi and Matsuura, 2012).The viral protease cleaves the remaining part left, producing the six non-structural proteins in which NS3 protease is also present (Honget al., 2018).

As the liver isthe main organ being infected by $\mathrm{HCV}$, a liver function test is performed to examine the liver dysfunction (Akram et al., 2017).Liver function test inspects the presence of different enzymes activities like enzyme aminotransferases is found five times greater than the normal limits in the tissue and body fluids which indicates hepatitis in patients. Moreover, these enzymes are not normally present in the serum sample,and if present, liver damage is suggested.The problem with $\mathrm{HCV}$ relates to the late diagnosis due to which proper and timely treatment is not given to the patients. It happens because of late visual symptoms which in turn causes high mortality and morbidity rates (Moustafaet al., 2012). This causes the disease burden within the population all around the globe.To provide proper treatment and improved survival rates, early diagnosis is necessary. According to a study HCV has become a global health threat and holds fifth and ninth position among men and women causing Hepatocellular carcinoma
(HCC), respectively (Mittal, 2013).It causes cancer-related mortality by becoming the second most dangerous disease in the world by diagnosing more than half a million cases every year (Nomairet al., 2019). Also, it cannot be denied that HCC has become one of the major risk factor of $\mathrm{HCV}$. It is very difficult to diagnose Liver cancer and hence it calls for better approaches to diagnose primary liver cancer efficiently and successfully (Qin et al., 2010). Due to the absence of potential biomarkers for early diagnosis, HCC is thought to be nearly incurable (Ressomet al., 2012). The liver is the main hub for metabolization and conditions like liver damage or HCC disrupts very basal, primitive and important processes of metabolism which includes glycolysis, gluconeogenesis, etc.chronic HCV infection disruptsthe normal functioning of the metabolism and lead to abnormalities within the process (Chen et al., 2019).This disorder in the normal processing function of the body can be used in the prognosis of $\mathrm{HCV}$ infection(Bugianesiet al., 2012).

During the malignancy of HCC cells, increased demand for energy is fulfilled by the glycolysis process. Also, the process of gluconeogenesis causes the increase in turnover of glucogenic amino acids like glycine, alanine, etc and some free fatty acids. This property is used in metabolome analysis which provides a better approach and good potential in finding the alternatives for early diagnosis of HCV and HCC. Another approach of lipidomic analysis can provide a 
new biomarker for diagnosis as some studies suggest that downregulation of FA oxidation; certain saturated lipids catabolism which shows high AFP level seen in patient serum sample (Björnsonet al., 2015;Beyoğluet al., 2013; Pattersonet al., 2011).HCV is known fora symptom like a steatosis and it encourages lipidosis to make the environment rich in lipid which is in favor ofthe virus to grow rapidly. This synergistic effect of HCV infection with lipid turnover helps in the activation and expression of specific transcription factors which are involved in the increase of FA, triglycerides and cholesterol (Syedet al., 2010).Also, overall disruption in metabolism gives rise to the possibility of many disease progressions such as type 2 diabetes mellitus in inclined individuals, nonalcoholic fatty acid liver disease and already mentioned HCC (Kaddai and Negro, 2011; Fu and Prasad, 2014).This study contains a detailed study about biochemical profiling and investigation to search for potent biomarkers for the diagnosis and detection of $\mathrm{HCV}$ infection. The research in this paper includes the data relevant to the different age groups among both the genders of the human population.

\section{Materials and Methods}

This study considered 96 (5ml) EDTA blood samples of suspected HCV infected patients. These samples were collected from the different hospitals in the Dehradun, Uttarakhand, India, including the OPDs and IPDs of Gastroenterology, Medicine,
Gynecology, Pediatrics, Tuberculosis, Chest and Surgery. 96 EDTA blood samples were collected and the RNA was extracted from the QIAamp Viral RNA mini kit (Cat. no. 52904). The template for $\mathrm{HCV}$ quantification was served by extracted RNA using the machine named as Rotor Gene Q 5 Plex Real-Time PCR machine. After the amplification and quantification, further analysis regarding viral load is estimated. The master mix was prepared by the Artus Amplification Kit from Qiagen for the HCV RNA quantification. The HCV RG Master reagents naming A and B with reverse transcription enzyme were used for specific amplification of 5'-3' untranslated region (UTR) at 240 bp region of $\mathrm{HCV}$ genome. The biochemical investigation is performed using RT-PCR in this study to understand the biochemistry behind the HCV infection.

\section{Results}

The viral load was studied using the RT-PCR to quantify and detect the presence of $\mathrm{HCV}$ RNA in the patient serum sample. The amplification curve is studied for studying the HCV RNA Viral load (Figure 1). All 96 samples were studied for the biochemical profiling using the Rotor-Gene Q-QIAGEN-5 Plex Real-Time Thermal Cycler. Out of 96 samples collected for HCV RNA biochemical profiling, $60.42 \%$ i.e. 58 cases were found with heavy viral load whereas $39.58 \%$, i.e., 38 cases were such in which specific target for HCV infection was not detected (Figure 2). 
The biochemical investigation was performed on 96 cases which includes SGOT (Serum Glutamic-Oxaloacetic Transaminase), SGPT (Serum Glutamic-Pyruvic Transaminase), Alkaline Phosphatase, albumin and globulin with high HCV RNA viral load i.e. more than $34 \mathrm{IU} / \mathrm{ml}(\geq 34 \mathrm{IU} / \mathrm{ml})$ and also cases in which target was detected were also considered. The

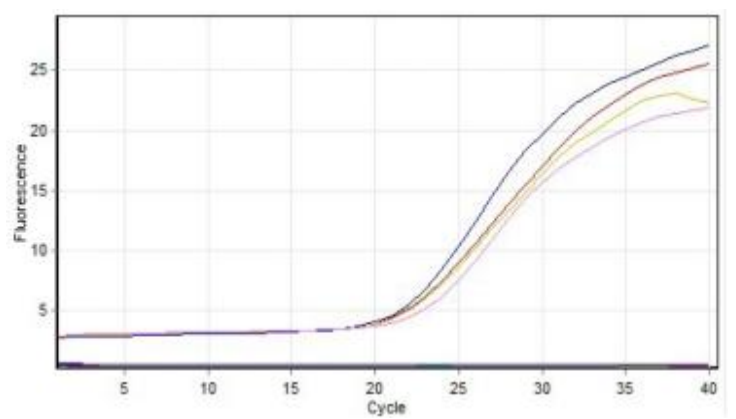

Fig. 1 parameters related to SGOT, SGPT, Alkaline phosphatase, Bilirubin and Globulin were found to be elevated in 58 cases with more than $34 \mathrm{IU} / \mathrm{ml}(\geq 34 \mathrm{IU} / \mathrm{ml})$. The elevation of $46.55 \%$ was found in 27 cases, $41.37 \%$ was found in 24 cases, $43.1 \%$ was found in 25 cases, $24.13 \%$ was found in 14 cases and $26.66 \%$ was found in 12 cases.

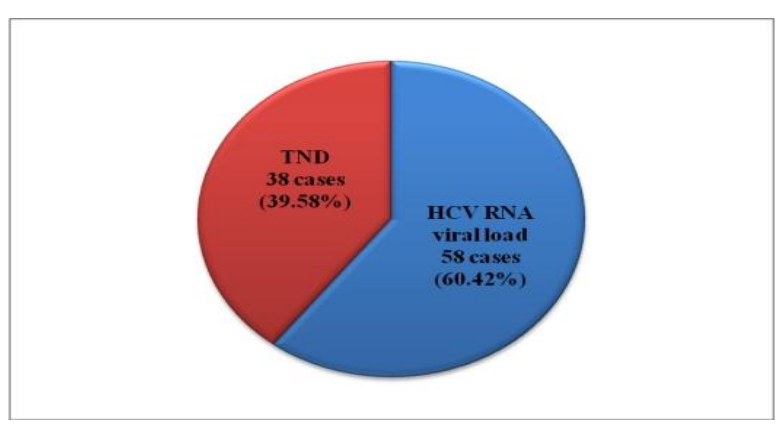

Fig. 2

Figure 1. Amplification curve for the high viral load of HCV in RT-PCR machine.

Figure 2. Pie chart depicting the percentage of cases found with high HCV RNA viral load and Target not detected (TND).

A correlation between the HCV RNA viral loads concerning biochemical profiling was established in this study in which 96 cases were considered for biochemical profiling for the presence of HCV viral load. 58 cases were found in which HCV RNA viral load was greater than $34 \mathrm{IU} / \mathrm{ml}(>34 \mathrm{IU} / \mathrm{ml})$, on the other hand in 38 cases, no target was detected. The analysis states that the 58 cases with $\mathrm{HCV}$ RNA viral load were greater than $34 \mathrm{IU} / \mathrm{ml}$ (>34 IU/ml), the levels of SGOT, SGPT, AP, Bilirubin and Globulin was raised by $46.55 \%$ in 27 cases, $41.37 \%$ in 24 cases, $43.1 \%$ in 25 cases, $24.13 \%$ in 14 cases and $39.65 \%$ in 23 cases, respectively.. The evaluation of the levels of SGOT, SGPT, AP, Bilirubin and Globulin in 38 cases in which target was not detected was found to be $39.47 \%$ in 15 cases, $21.05 \%$ in 8 cases, $34.21 \%$ in 13 cases, $23.68 \%$ in 9 cases and $13.15 \%$ in 5 cases respectively as shown in Table 1 .

According to the study performed above, it is revealed that people with age group 21-40 and 41-60 years were more prominent in getting the HCV infection. $80 \%$ infected patients belonged to the 21-40 years age group and $54.05 \%$ infected patients belonged to the 41 60 years age group (Table 2, Figure 3). 
Table 1: Comparative results interpretation for biochemical investigations and HCV RNA viral load.

\begin{tabular}{|c|c|c|c|c|c|c|}
\hline $\begin{array}{l}\text { Category of } \\
\text { cases }\end{array}$ & $\begin{array}{l}\text { Total } \\
\text { no of } \\
\text { cases }\end{array}$ & $\begin{array}{l}\text { Range of } \\
{ }^{1} \text { SGOT }(14- \\
\text { 36) U/L }\end{array}$ & $\begin{array}{lr}\text { Range } & \text { of } \\
{ }^{2} \text { SGPT } & (9-12) \\
\text { U/L } & \end{array}$ & $\begin{array}{l}\text { Range of } \\
{ }^{3} \mathrm{AP} \quad(38- \\
126) \mathrm{U} / \mathrm{L}\end{array}$ & $\begin{array}{l}\text { Range } \\
\text { Bilirubin } \quad \text { of } \\
1.3) \mathrm{mg} / \mathrm{dl}\end{array}$ & $\begin{array}{l}\text { Range of } \\
\text { globulin }(2.3- \\
3.5) \mathrm{g} / \mathrm{dl}\end{array}$ \\
\hline $\begin{array}{l}\text { Upper value of } \\
\text { normal range }\end{array}$ & 96 & $46(47.91 \%)$ & $39(40.62 \%)$ & $\begin{array}{l}31 \\
(32.29 \%)\end{array}$ & $25(26.04 \%)$ & $29(30.20 \%)$ \\
\hline $\begin{array}{l}\text { Lower value of } \\
\text { normal range }\end{array}$ & 96 & $16(16.66 \%)$ & $11(11.45 \%)$ & $\begin{array}{l}21 \\
(21.87 \%)\end{array}$ & $23(23.95 \%)$ & $26(27.08 \%)$ \\
\hline Normal range & 96 & $34(35.41 \%)$ & $46(47.91 \%)$ & $\begin{array}{l}44 \\
(45.83 \%)\end{array}$ & $48(50.00 \%)$ & $41(42.70 \%)$ \\
\hline $\begin{array}{l}\text { HCV RNA } \\
\text { viral load }\end{array}$ & 58 & $27(46.55 \%)$ & $24(41.37 \%)$ & $\begin{array}{l}25 \\
(43.10 \%)\end{array}$ & $14(24.13 \%)$ & $23(39.65 \%)$ \\
\hline $\begin{array}{l}\text { Target not } \\
\text { detected. }\end{array}$ & 38 & $15(39.47 \%)$ & $8(21.05 \%)$ & $\begin{array}{l}13 \\
(34.21 \%)\end{array}$ & $9(23.68 \%)$ & $5(13.15 \%)$ \\
\hline
\end{tabular}

Table 2: Age wise distribution of Hepatitis C Viral infection.

\begin{tabular}{llll}
\hline Age group (In years) & Total cases & $\begin{array}{l}\text { Cases with HCV RNA } \\
\text { viral load detected }\end{array}$ & TND \\
\hline $\mathbf{0 - 2 0}$ & $06(6.2 \%)$ & $02(33.33 \%)$ & $04(66.66 \%)$ \\
$\mathbf{2 1 - 4 0}$ & $35(36.45 \%)$ & $28(80.0 \%)$ & $07(20.00 \%)$ \\
$\mathbf{4 1 - 6 0}$ & $37(38.58 \%)$ & $20(54.05 \%)$ & $17(45.94 \%)$ \\
Above 60 & $18(18.75 \%)$ & $8(44.44 \%)$ & $10(55.55)$ \\
Total & 96 & $58(60.41 \%)$ & $38(39.58 \%)$ \\
\hline
\end{tabular}

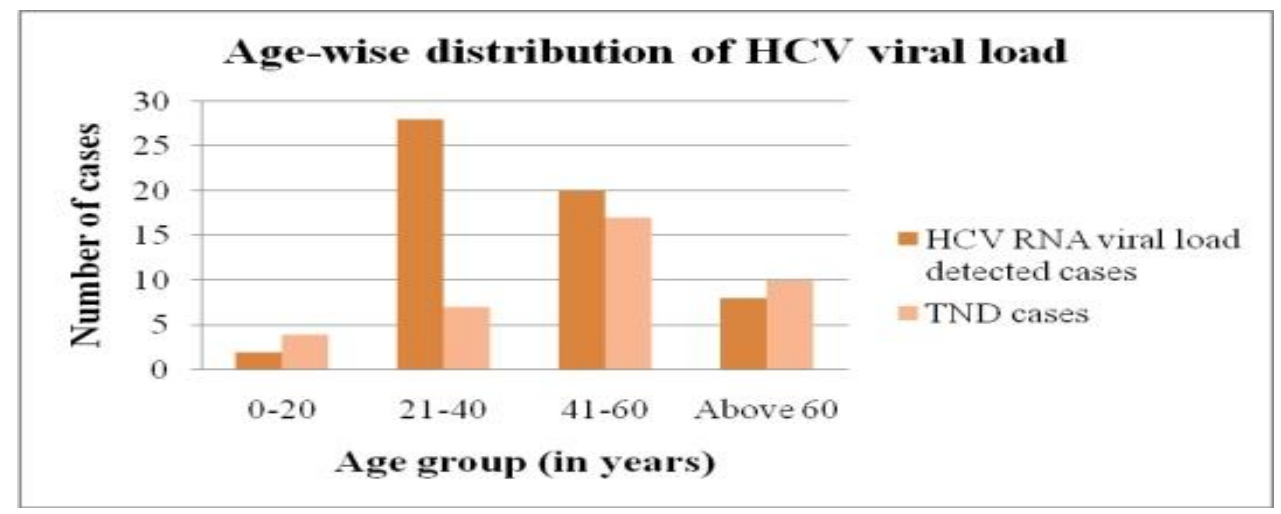

Figure 3. Age-wise distribution of high viral load and TND for Hepatitis C Virus.

\section{Discussion}

The use of biochemical markers is one of the most potent methods as there are many biochemical and metabolic changes that occur during the $\mathrm{HCV}$ infection. There are numerous conflicts reported with the reverse transcription PCR (RT-PCR) method involving alanine transaminase (ALT), histological inflammation degree and the levels of HCV RNA in the serum. It is a very well-known fact that RT-PCR is a very sensitive and reliable method of diagnosis and 
detection. The clinical significance is linked with patients suffering from chronic $\mathrm{HCV}$ infection and elevated ALT levels in the serum. The most heavily present biochemical marker, ALT is present within the liver and released into the bloodstreams only during some infection or injury to the liver. Hence, whenever there is an elevation of ALT in the bloodstream or serum levels of a patient, problems with the liverlike infection or tissue injury are generally suggested. Such patients are veterans for liver function tests to confirm the elevated levels of enzymes in the blood or serum which is not normally present there. The SGOT are found in many tissues of the body like the liver, heart, muscle, kidney and brain. Its level is increased in the bloodstream only if some damage has occurred to the tissues. Liver injury marks the high levels of SGOT. This study reveals that among the three groups HCV genotypes, nit was the SGOT serum level which was found to be varied greatly whereas other biochemical parameters were mostly unbalanced, although change remained non-significant as reported earlier. Also, a low level of globulin is observed in $\mathrm{HCV}$ infection which marks for cirrhosis i.e., advanced liver disease. The levels of globulin can vary from up and down although it has been seen that the low level of globulin can cause edema. The fluid accumulation can occur in the abdomen (as ascites) or it may accumulate in the leg. Such low levels of proteins in the blood also indicate the problems with liver and impaired functioning of the liver. Another potent biochemical marker is the alkaline phosphatase. The alkaline phosphatase high level is not linked with inflammation or damage. Also, the high level of alkaline phosphatase can occur during the blockage of flow in the biliary tract or build-up of the pressure in the liver. Gallstone or scarring can cause such blockage and pressure in the bile ducts. By the overall biochemical investigation and study, it can be clearly stated that the biochemical marker levels like SGOT, SGPT, alkaline phosphatase, bilirubin and globulin are increased in significant amounts in the serum/blood of the patients with high $\mathrm{HCV}$ RNA viral load cases whereas such elevation is observed in the case of target not detected in the current study. Viral infection also varies with the age of the individuals and their immunity. There is always a risk factor of developing steatosis, cirrhosis and hepatocellular carcinoma associated with the HCV infection (Licataet al., 2019).The cases of age group 41-60 years had the highest HCV RNA viral load with 37 cases in the present study. This occurs because of the repeated exposure of the blood infected by $\mathrm{HCV}$ infection.Also, the cases belonging to $0-20$ years were found to be least susceptible with only 2 positive cases of $\mathrm{HCV}$ infection was found. It might occur because of protective antibody titre due to $\mathrm{HCV}$ vaccination at an early age.Many approaches are being explored for treating $\mathrm{HCV}$ and new studies revealed the importance of marine products for the synthesis of silver nanoparticles (SNPs) withinvitro anti-HCV NS3 helicase and 
protease activity (Shady et al., 2020).SNPs are being used in many multi-therapeutic targets and their applications in treating the HCV(Haggaget al., 2019).Although, there is a wide chance of silver toxicity due to which this method is not yet widely accepted but they provide wide range of pharmaceuticals acting as anti-bacterial and anti-viral agents (Amin et al., 2012; Sekhar et al., 2018).

Besides the approaches present, it is very important to search for more advanced and proper approaches which can be used in the successful and accurate diagnosis of HCC. The field of metabolomics provides a potential for searching newer biomarkers that can be proved in the successful and timely diagnosis of HCC and HCV. This field of metabolomics belongs to the small molecular intermediates study and study of the product of metabolism. This method allows exploration to diseases of various kinds which includes small gene changes and protein expressions(Nomairet al., 2019). Another biomarker can be based on lipidomic analysis as aberrant lipid metabolism is observed in HCC patients who cause unusual AFP levels, high concentration of saturated triglycerides and low concentrations of polysaturated triglycerides in the tissue sample of patient serum sample ( $\mathrm{Li}$ et al., 2017; Lin et al., 2017).

Even after successful diagnosis, the viable treatment needed exploration of anti-HCV drugs and vaccines but this task has not been proven to be easy for time being (Shady et al., 2018).Drugs can be developed by targeting the protein degradation machinery of $\mathrm{HCV}$ (de
Wispelaere et al., 2019).The drugs used in anti-HCV like Sofosbuvir, Ribavirin and Remdisivir etc. are also being tested against COVID-19. Mostly, GTP derivatives are being used as specific inhibitors against COVID-19 (Elfiky, 2020). Different molecular targets related to miRNA are also being explored to treat HCV infection (El-Maraghyet al., 2020).

\section{Conclusion}

Hepatitis C Virus causes liver infection. Any infection in the liver tissue causes the liver enzymes to be released in the bloodstream which does not occur during the normal functioning of the liver. This release in the bloodstream causes the variation of serum biochemistry and this deviation from normalcy is used as a potent biomarker for the $\mathrm{HCV}$ or HCC diagnosis and detection. Regarding the biochemical investigation, a new era in the coming future would define the potential of various biochemical markers. As the biochemistry of humankind is very well defined when we consider the state of normalcy and also the case of disease or infection, any disruption within the tissue or organs causes an interruption in the overall biochemistry of the body. Such changes or disruptions are needed to be detected accurately for the early diagnosis. The biochemical findings also included SGOT, SGPT, Alkaline phosphatase, Bilirubin and Gobulin parameters found in the HCV RNA viral load cases. The study of metabolomics and lipidomics also provide great potential in the HCV or HCC diagnosis as HCV infection 
directly causes changes in carbohydrate and lipid metabolism. Such changes in metabolism can be seen atthe cell or tissue level. Extensive study of such changes can help us to determine the different levels of biochemical factors and markers and the causes behind their abnormal presence or absence and increase or decrease.

\section{Supplementary Materials}

No supplementary material

\section{Acknowledgments}

Authors like to acknowledge the Department of Microbiology, Shri Guru Ram Rain University, Dehradun, Uttarakhand.

\section{Conflicts of Interest}

There are no conflicts of interest.

\section{References}

Akram Y, Mahmood Z, Riaz M, Javed I, Shahid M, Batool T, Shah SMA, Munir, $\mathrm{N}$ and Tahir IM (2017). Biochemical profiling of tuberculosis patients coinfected with hepatitis C virus. Eur. J. Inflamm. 15: 5-42

AminM, Anwar F, Janjua MR, Iqbal MA, Rashid U (2012).Green synthesis of silver nanoparticles through reduction with Solanum xanthocarpum L. berry extract: characterization, antimicrobial and urease inhibitory activities against Helicobacter pylori. Int. J. Mol. Sci., 13: 41-9923.

Beyoğlu D, Imbeaud S, Maurhofer O, Bioulac-Sage P, Zucman-Rossi J., Dufour, J.F. and Idle JR (2013).Tissue metabolomics of hepatocellular carcinoma: tumor energy metabolism and the role of transcriptomic classification. Hepatol. 58: 38-229.

Björnson E, Mukhopadhyay B, Asplund A, Pristovsek N, Cinar R, RomeoS, Uhlen M, Kunos G, Nielsen J, Mardinoglu A (2015).Stratification of hepatocellular carcinoma patients based on acetate utilization. Cell Rep. 13: 26 - 2014.

Bugianesi, E., Salamone, F., and Negro, F. (2012).The interaction of metabolic factors with $\mathrm{HCV}$ infection: does it matter?. J. Hepatol. 56: S56-65.

Chen, J., Zhou, Y., Zhuang, Y., Qin, T., Guo, M., Jiang, J., Niu, J., Li, J.Z., Chen, X. and Wang, Q. (2019). The metabolic regulator small heterodimer partner contributes to the glucose and lipid homeostasis abnormalities induced by hepatitis $\mathrm{C}$ virus infection. Metabolism.100: 153954.

De Wispelaere, M., Du, G., Donovan, K.A., Zhang, T., Eleuteri, N.A., Yuan, J.C., Kalabathula, J., Nowak, R.P., Fischer, E.S., Gray, N.S. and Yang, P.L. (2019).Small molecule degraders of the hepatitis $\mathrm{C}$ virus protease reduce susceptibility to resistance mutations. Nat. Commun. 10: 1-11

Elfiky AA (2020).Anti-HCV, nucleotide inhibitors, repurposing against COVID19. Life Sci. 117477.

El-MaraghySA, Adel O, Zayed N, Yosry A, El-Nahaas SM and, Gibriel AA (2020).Circulatory miRNA-484, 524, 615 
and 628 expression profiling in $\mathrm{HCV}$ mediated HCC among Egyptian patients; implications for diagnosis and staging of hepatic cirrhosis and fibrosis. J. Adv. Res. 22: 57-66.

Fu, J. and Prasad, H.C. (2014).Changing epidemiology of metabolic syndrome and type 2 diabetes in Chinese youth. Curr. Diabetes Rep.14: 447.

Fujimoto Y, Salam KA, Furuta A, Matsuda Y, FujitaO, Tani H, Ikeda M, Kato N, Sakamoto N, Maekawa S, Enomoto N (2012).Inhibition of both protease and helicase activities of hepatitis $\mathrm{C}$ virus NS3 by an ethyl acetate extract of marine sponge Amphimedon sp. PLoS One. 7 : e48685.

Haggag, E.G., Elshamy, A.M., Rabeh, M.A., Gabr, N.M., Salem, M., Youssif, K.A., Samir, A., Muhsinah, A.B., Alsayari, A., and Abdelmohsen, U.R. (2019).Antiviral potential of green synthesized silver nanoparticles of Lampranthus coccineus and Malephora lutea.Int. J. Nanomedicine. 14: 6217.

Hong, T.T., Dat, T.T., Cuc, N.T. and Cuong, P.V. (2018). Mini-review protease inhibitor (PI) and Pis from spongeassociated microorganisms. Vietnam J. Sci. Technol. 56: 405

Kaddai, V. and Negro, F. (2011).Current understanding of insulin resistance in hepatitis C. Expert. Rev. Gastroenterol. Hepatol. 5: 16 - 503.

Kuriyal M, Bhandari A, Suman AK, Shootha D, Gairola Y, Sharma N, Nautiyal SC
(2019).Hepatitis C Virus (HCV) and its Genetic Diversity in clinical Isolates from Uttarakhand Population. J. Drug Deliv. Ther. $9: 4-280$.

Li, Z., Guan, M., Lin, Y., Cui, X., Zhang, Y., Zhao, Z. and Zhu, J. (2017).Aberrant lipid metabolism in hepatocellular carcinoma revealed by liver lipidomics. Int. J. Mol. Sci., 18: 2550.

Licata, A., Minissale, M.G., Montalto, F.A. and Soresi, M. (2019).Is vitamin D deficiency predictor of complications development in patients with HCVrelated cirrhosis?. Intern. Emerg. Med. 14: $7-735$.

Lin L, Ding Y, Wang Y, Wang Z, Yin X, Yan G, ZhangL, Yang $\mathrm{P}$ and, ShenH (2017).Functional lipidomics: palmitic acid impairs hepatocellular carcinoma development by modulating membrane fluidity and glucose metabolism. Hepatol., 66: 48-432.

Mahmood Z, Shakoor A, Riaz M (2013).Investigation of selective biochemical markers from chronic hepatitis $\mathrm{C}$ patients in relation to environmental pollutants. World Appl. Sci. J. 24: 90-1084.

MittalS. (2013). Epidemiology of hepatocellular carcinoma. J. Clin. Gastroenterol. 47: 2-6.

Moriishi K, Matsuura Y (2012).Exploitation of lipid components by viral and host proteins for hepatitis $\mathrm{C}$ virus infection. Front. Microbiol. 3: 54. 
Moustafa T, Fickert P, Magnes C, Guelly C, Thueringer A, FrankS, KratkyD, Sattler W, Reicher H, Sinner F, Gumhold J (2012).Alterations in lipid metabolism mediate inflammation, fibrosis, and proliferation in a mouse model of chronic cholestatic liver injury. Gastroentrology. 142: 51-140.

Nelson, P.K., Mathers, B.M., Cowie, B., Hagan, H., Des Jarlais, D., Horyniak, D., and Degenhardt, L. (2011).Global epidemiology of hepatitis B and hepatitis $\mathrm{C}$ in people who inject drugs: results of systematic reviews. Lancet. 83: 378-571.

Nomair, A.M., Madkour, M.A., Shamseya, M.M., Elsheredy, H.G. and Shokr, A. (2019). Profiling of plasma metabolomics in patients with hepatitis C-related liver cirrhosis and hepatocellular carcinoma. Clin. Exp. Hepatol. 5: 317.

Patterson, A.D., Maurhofer, O., Beyoğlu, D., Lanz, C., Krausz, K.W., Pabst, T., Gonzalez, F.J., Dufour, J.F. and Idle, J.R. (2011).Aberrant lipid metabolism in hepatocellular carcinoma revealed by plasma metabolomics and lipid profiling. Cancer Res. 71: 600 - 6590

Qin, T., Liu, H., Song, Q., Song, G., Wang, H.Z., Pan, Y.Y., Xiong, F.X., Gu, K.S., Sun, G.P. and Chen, Z.D. (2010).The screening of volatile markers for hepatocellular carcinoma. Cancer Epidemiol. Prev. Biomark. 19: 53- 2247.

Ressom HW, Xiao JF, Tuli L, Varghese RS, Zhou B, Tsai TH, Ranjbar MRN, Zhao Y, Wang J, Di Poto C, Cheema, A.K.
(2012).Utilization of metabolomics to identify serum biomarkers for hepatocellular carcinoma in patients with liver cirrhosis. Analytica. Chimica. Acta. 743: 90-100.

Sekhar, E.C., Rao, K.S., Rao, K.M. and Alisha, S.B. (2018).A simple biosynthesis of silver nanoparticles from Syzygium cumini stem bark aqueous extract and their spectrochemical and antimicrobial studies. J. Appl. Pharm. Sci .8: 9-73.

Shady NH, Fouad MA, Ahmed S, PimentelElardo SM, Nodwell JR, Kamel MS, Abdelmohsen UR (2018).A new antitrypanosomal alkaloid from the Red Sea marine sponge Hyrtios sp. J. Antibiot. 71: 9- 1036

Shady NH, Khattab AR, Ahmed S, Liu M, Quinn RJ, Fouad MA, Kamel MS, Muhsinah AB, Krischke M, Mueller MJ, Abdelmohsen, U.R. (2020).Hepatitis C Virus NS3 Protease and Helicase Inhibitors from Red Sea Sponge (Amphimedon) Species in Green Synthesized Silver Nanoparticles Assisted by in Silico Modeling and Metabolic Profiling. Int. J. Nanomedicine. 15: 3377.

Syed GH, Amako Y, Siddiqui A (2010).Hepatitis C virus hijacks host lipid metabolism. Trends Endocrinol Metab. 21: 33 - 40 . 